\title{
STUDY OF ANTIOXIDANT ACTIVITY OF HINDERED PHENOLS IN BULK OIL AND THIN FILM OXIDATION CONDITIONS IN LUBRICANTS
}

\author{
K.T. Sutar ${ }^{1, *}$ and P.U. Singare ${ }^{2}$ \\ ${ }^{1}$ Department of Chemistry, Shri Jagdish Prasad Jhabarmal Tibrewala University, Vidyanagari, Jhunjhunu \\ -333 001, (Rajasthan), India \\ ${ }^{2}$ Department of Chemistry, Bhavan's College, Munshi Nagar, Andheri West, Mumbai-400058, \\ (Maharashtra), India \\ *E-mail: sutar.kashinath@gmail.com, pravinsingare@gmail.com
}

\begin{abstract}
Antioxidant activity of three substituted hindered phenolic antioxidants is studied in bulk oil oxidation and thin film oxidation conditions. Test conditions of The Institute of Petroleum test method IP-48 are used for evaluation of inhibition activity of antioxidants in bulk oil oxidation regime and Pressure Differential Scanning Calorimetry (PDSC) is used for thin film oxidation regime. Para position of phenolic antioxidant has a substitution of alkyl, ester and thioether linkage in these selected antioxidants. Antioxidant activity of thioether substitution is found better that ester and alkyl substitution. Ester substitution in para position has better inhibition activity than alkyl substitution. Relative Inhibition activity of selected antioxidants is similar in both bulk oil oxidation process (which is slower oxidation reaction) and in thin film oxidation (which is relatively faster oxidation reaction.)

Keywords: Antioxidants, base oils, hindered phenolics, bulk oil oxidation, thin film oxidation, IP-48, differential scanning calorimetry.
\end{abstract}

(C) RASĀYAN. All rights reserved

\section{INTRODUCTION}

Oxidation is one of the main causes of deterioration of lubricant and decline in its service life. It is the prime reason for many lubricant problems such as deposit formation, thickening of oil, rust and corrosion, etc ${ }^{1,}$

2. Therefore, oxidation inhibition is essential for lubricant to do its role for sufficiently long life. Various antioxidants are being extensively used in various lubricant formulations either alone or in synergies with other antioxidants.

Oxidative degradation of lubricants- in automotive engines- occurs in two main reactions- bulk oil oxidation and thin-film oxidation. Bulk oil oxidation generally takes place at a slower rate in a large oil body, such as in crankcase sump. Bulk oil oxidation results in an increase in the acid value of the oil, thickening of oil and eventually the formation of oil-insoluble polymers. The polymers may combine with other impurities (metals, ash, water, partially burnt fuel, etc.), with the mixture dropping out of the oil collectively as sludge. Thin-film oxidation is the faster reaction in which small quantity of oil is exposed to quite high temperatures and air (oxygen). Under such conditions, hydrocarbons of lubricants rapidly decompose to form polar oil oxidation products. These products built up rapid on the metal surface, leading to the formation of varnish. Thin film oxidation occurs on the cylinder liner. ${ }^{3}$

The oxidation of hydrocarbon is a free radical process and involves initiation, propagation, branching and termination as four major stages ${ }^{4}$. The oxidation process in the liquid phase can be catalyzed by metals or inhibited by various mechanisms. Due to thermal energy, homolytic decomposition of hydrocarbon forms alkyl radicals. These radicals react with oxygen to form peroxy radicals. Hydrogen-donating antioxidants $(\mathrm{AH})$, such as hindered phenols compete with the organic substrate $(\mathrm{RH})$ for peroxy radicals. This reduces the rate of propagation reaction and thus inhibits the oxidation process. Hindering the phenolic hydroxyl group with at least one bulky alkyl group in the ortho position appears necessary for high antioxidant activity. Steric hindrance decreases the ability of a phenoxyl radical to abstract a hydrogen atom from the substrate and thus reduces the formation of an alkyl radical capable of initiating oxidation ${ }^{5}$. 
Field performance evaluation of formulated lubricating oil consumes a lot of resources and time. Before actual field evaluation of new oil in the fleet, it is essential to conduct a thorough investigation of the performance through laboratory tests. IP- $48^{6}$ is one of the best suitable bulk oil oxidation tests whereas a thermal analysis technique such as $\mathrm{PDSC}^{7}$ is a quick and most suitable thin film oxidation test. DSC, TGA (Thermogravimetric Analysis) has been used widely by various researchers for evaluation of various antioxidants and mineral as well as biobased lubricant base stocks ${ }^{8-11}$.

Pressure Differential scanning calorimeter (PDSC) is one of the important tools used to assess the oxidative stability of oil in thin film oxidation regime, by measuring Oxidation Induction Time (OIT), which is the time at which oxidation of material starts and is signalled by an abrupt exotherm. ASTM has developed a test method for measurement of OIT of Lubricating Oils by Pressure Differential Scanning Calorimetry (PDSC). In PDSC, the pressure in the cell minimizes evaporation loss effects.

In this study, we have selected three hindered phenolic antioxidants, first with simple molecular structure, second with the substitution of electron donating functional group chain and the third one with thioether linkage in para substitution. These additives are blended with API Group II base oil. These blends are tested with IP 48 and PDSC to study the influence of substitution and molecular structure of antioxidant additives on oxidative stability of lubricant blends.

\section{Materials}

\section{EXPERIMENTAL}

API Group II base oil was selected for this study as the majority of engine oils being blended with this type of base oil. The physicochemical test data of these base oils is given in Table-1.

Table-1: Physicochemical Data of Base Oil Selected for Study

\begin{tabular}{l|l|l}
\hline Property & Method & Test results \\
\hline Kinematic Viscosity @ $40^{\circ} \mathrm{C}$ & ASTM D445 & $32.016 \mathrm{cSt}$ \\
\hline Kinematic Viscosity @ $100^{\circ} \mathrm{C}$ & ASTM D445 & $5.6859 \mathrm{cSt}$ \\
\hline Viscosity Index & ASTM D2270 & 122 \\
\hline Sulphur Content & ASTM D5453 & $<0.01 \%$ \\
\hline Nitrogen Content & ASTM D5762 & $<0.01 \%$ \\
\hline Aromatic content & IS 13155 & $0.1 \%$ \\
\hline
\end{tabular}

Three different hindered phenolic antioxidants with different substitutions at the para position are selected for this study. Their chemical \& structural formulae and physical properties are given in Table-2.

Table-2: Details of Hindered Phenolics Selected for Study

\begin{tabular}{l|l|l|l}
\hline & \multicolumn{1}{|c|}{ AO-I } & \multicolumn{1}{c}{ AO-II } & \multicolumn{1}{c}{ AO-III } \\
\hline $\begin{array}{l}\text { Chemical } \\
\text { Name }\end{array}$ & $\begin{array}{l}\text { 2,6-bis(1,1- } \\
\text { dimethylethyl)-4- } \\
\text { methylphenol }\end{array}$ & $\begin{array}{l}\text { Octyl-3,5-di-tert-butyl-4- } \\
\text { hydroxy-hydrocinnamate }\end{array}$ & $\begin{array}{l}\text { 3,5-bis(1,1-dimethyl)-4- } \\
\text { hydroxybenzenepropionic acid thiodi- } \\
2,1 \text {-ethanediyl ester }\end{array}$ \\
\hline CAS No. & $128-37-0$ & $125643-61-0$ & $41484-35-9$ \\
\hline $\begin{array}{l}\text { Structural } \\
\text { formula }\end{array}$ & & &
\end{tabular}

\section{Sample Preparation}

Three different lubricant blends were prepared with base oil and antioxidant. O.5 mass/\% of antioxidant was dissolved in base oil by mechanical stirring at $600 \mathrm{rpm}$ while heating at $60^{\circ} \mathrm{C}$ on a hot plate for 30 
minutes. Samples were allowed to cool down to room temperature and stored in amber colored bottles to avoid any photochemical degradation. The blend composition matrix is given in Table-3.

Table-3: Blend Composition Matrix

\section{IP 48 Oxidation}

\begin{tabular}{c|c|c|c}
\multicolumn{4}{c}{ Table-3: Blend Composition Matrix } \\
\hline & Blend -1 & Blend -2 & Blend -3 \\
\hline AO-I & $0.5 \%$ & -- & -- \\
\hline AO-II & -- & $0.5 \%$ & -- \\
\hline AO-III & -- & -- & $0.5 \%$ \\
\hline Base Oil & $99.5 \%$ & $99.5 \%$ & $99.5 \%$ \\
\hline
\end{tabular}

Oxidation test vessels were first cleaned by soaking in concentrated sulphuric acid for overnight and then washing with tap water and distilled water repeatedly. It was then dried in $100^{\circ} \mathrm{C}$ Glassware oven for at least three hours and then allowed to cool to room temperature before use. Empty test vessel with ground glass head was then weighed to nearest 0.1 gm weight. Approx. $40 \mathrm{ml}$ oil sample then charged and then weighed the test vessel with the sample to nearest $0.1 \mathrm{gm}$. The vessel with the sample then charged in an oil bath maintained at $200 \pm 0.5^{\circ} \mathrm{C}$. Air supply with a flow rate $15 \pm 0.25 \mathrm{l} / \mathrm{h}$ is then connected from a compressor. Adjusted the air flow, once oil reaches the test temperature and then maintained the test conditions for $6 \mathrm{~h} \pm 10$ minutes. Removed the oxidation tube from the bath and allowed to cool and stand at room temperature for $12 \mathrm{~h}$. repeated the heating procedure after $12 \mathrm{hr}$. with air flow. After second $6 \mathrm{hr}$. cycle removed the oxidation tubes from bath and then cooled to room temperature. The oxidized oil is then tested for oxidative degradation.

The oxidation tubes are then weighed to nearest $0.1 \mathrm{~g}$ to calculate the evaporation loss during oxidation. The oxidized oil was then subjected to following tests:

1. Change in Kinematic viscosity

2. Change in acid number

3. Carbon residue measurement

4. Measurement of oxidation products by FT-IR.

\section{Kinematic Viscosity}

Kinematic Viscosity at $40^{\circ} \mathrm{C}$ was measured with the Herzog Multi-Range Viscometer (HVM 472) which is fully automated equipment to measure the direct kinematic viscosity of transparent and opaque liquids using capillary viscometer. A test was conducted in accordance with ASTM D445 ${ }^{12}$.

\section{Acid Number}

The total acid number (TAN) of un-oxidized oil and oil oxidized in the IP-48 test was analyzed using the test procedure as per ASTM D $664^{13}$. The working procedure determines the sum of all acid compounds present in oil samples by an acid-base titration using standardized $\mathrm{KOH}$ as titrant. TAN is expressed in $\mathrm{mg}$ of $\mathrm{KOH}$ required per gm of the sample. Since samples are the non-aqueous type, they are diluted in a mix of toluene and isopropyl alcohol. The solvent for $\mathrm{KOH}$ is isopropyl alcohol.

Before titration of the sample, blank titration with $75 \mathrm{ml}$ of solvent is measured. For TAN of the sample, weigh approximately $1 \mathrm{~g}$ of oil to nearest $0.1 \mathrm{mg}$ in a 100-mL beaker and add $75 \mathrm{~mL}$ of solvent.

\section{Carbon Residue Measurement}

Micro Carbon Residue (commonly known as "MCR") is a laboratory test used to determine the amount of carbonaceous residue formed after evaporation and pyrolysis of oils under certain test conditions. The test suggests the oils coke-forming tendencies.

Tanaka's ACR-M3 automatic Micro Carbon Reside Tester was used for this analysis. Tests were conducted in accordance with ASTM D 4530 ${ }^{14}$. About $1 \mathrm{gm}$ sample is weighed accurately to $0.1 \mathrm{mg}$ in a glass vial of $2 \mathrm{ml}$ capacity. Vials such weighed are then placed in vial holder, which is having the capacity to hold twelve 
such vials. Holder with vials is placed in an MCR instrument oven chamber at room temperature and covered with a lid. The chamber is then purged with Zero Grade Nitrogen at $600 \mathrm{ml} / \mathrm{min}$ flow rate for 10 minutes. The Nitrogen flow rate then decreased to $150 \mathrm{ml} / \mathrm{min}$ oven heating started at a rate of $10^{\circ}$ to $15^{\circ} \mathrm{C} / \mathrm{min}$ up to $500^{\circ} \mathrm{C}$. Oven maintained at $500 \pm 2^{\circ} \mathrm{C}$ for 15 minutes. Furnace power then shuts off and allowed to cool freely to room temperature under nitrogen flow rate at $600 \mathrm{ml} / \mathrm{min}$. The vials are then weighed to nearest $0.1 \mathrm{mg}$ and carbon residue percentage is calculated.

\section{Measurement of Oxidation Products by FT-IR.}

To estimate the degree of oxidation, and to estimate the remaining useful life of the lubricants, the FTIR test method has been developed by the Joint Oil Analysis Program (JOAP) and approved by ASTM as ASTM Practice E 2412-04 for lubricant condition monitoring by trending ${ }^{15}$. The ASTM method was revised as E2412-10 16 .

In the current study, Perkin Elmer's FT-IR Spectrum 100 is used with Zn-Se liquid sample cell of $0.1 \mathrm{~mm}$ path length and DTGS detector (inbuilt). The infrared transmittance spectrum of the oil sample is acquired in the range of 4000 to $550 \mathrm{~cm}^{-1}$ with sufficient signal to noise ratio, in $\mathrm{Zn}$-Se cell.

DSC Model Q2000 from TA Instruments with Tzero PDSC cell was used for the studies. Aluminium and copper sample pans from TA instruments were used in the current study. High pressure in PDSC prevents the evaporation loss of lubricants and saturates the test sample with oxygen. This result in the speeding up of oxidation, as well as sharpening of the exotherm, as compared to normal DSC. PDSC experiments are conducted in an isothermal mode to measure oxidation induction time (OIT).

Isothermal PDSC was performed on $3 \pm 0.2 \mathrm{mg}$ of oil sample in open aluminium pan under pressure of $3500 \mathrm{kpa}$ of high purity oxygen. Oxygen flow through the cell was regulated at $100 \mathrm{~mL} \mathrm{~min}{ }^{-1}$. Oil samples were heated from an ambient temperature of $180^{\circ} \mathrm{C}$ at the heating rate of $100^{\circ} \mathrm{C} \mathrm{min}^{-1}$. Once the temperature is stabilized at $180^{\circ} \mathrm{C}$, pressurization of PDSC cell with oxygen, pressure, oxygen flow and temperature were adjustments were done within 2 minute time ${ }^{17}$. PDSC held at the isothermal mode until an exothermic peak of oxidation onset is detected. OIT of the sample was calculated by extrapolating the tangent drawn on the steepest slope of the corresponding exotherm curve to the baseline ${ }^{18}$.

\section{IP 48}

\section{RESULTS AND DISCUSSION}

\section{Weight Loss Analysis}

The weight loss occurs due to formation low molecular weight products and evaporation of these volatile species. Test results of weight loss of Blend 1, 2 and 3 are given in Table-4.

Table-4: IP 48: Weight Loss Analysis

\begin{tabular}{c|c|c|c|c|c|c}
\hline Blend & $\begin{array}{c}\text { The weight of } \\
\text { Empty Test } \\
\text { Cell, gm }\end{array}$ & $\begin{array}{c}\text { The weight of Test } \\
\text { Cell + Oil, } \\
\text { gm }\end{array}$ & $\begin{array}{c}\text { Sample } \\
\text { Weight, gm }\end{array}$ & $\begin{array}{c}\text { Final } \\
\text { Weight, gm }\end{array}$ & $\begin{array}{c}\text { Weight } \\
\text { Loss, gm }\end{array}$ & $\begin{array}{c}\% \\
\text { Weight } \\
\text { loss }\end{array}$ \\
\hline 1 & 129.430 & 163.491 & 34.061 & 159.971 & 3.5 & 10.3 \\
\hline 2 & 150.696 & 183.148 & 32.452 & 180.745 & 2.40 & 7.40 \\
\hline 3 & 152.094 & 188.879 & 36.785 & 186.837 & 2.04 & 5.55 \\
\hline
\end{tabular}

\section{Change in Kinematic Viscosity (KV)}

The Kinematic viscosity of samples before and after oxidation of oil was measured at $40^{\circ} \mathrm{C}$ in $\mathrm{Herzog}$ Multi-Range Viscometer (HVM 472). The ratio of viscosity after oxidation with that of before oxidation is reported as a change in viscosity. The rest results are given in Table-5.

Table-5: IP 48: Change in KV

\begin{tabular}{c|c|c|c}
\hline \multirow{2}{*}{ Blend } & \multicolumn{2}{|c|}{ Kinematic Viscosity @ 40 C, cSt } & Change in Viscosity \\
\cline { 2 - 4 } & Sample Before Oxidation, $\mathrm{V}_{0}$ & Sample after oxidation, V & V/Vo \\
\hline 1 & 31.857 & 96.505 & 3.029 \\
\hline
\end{tabular}


RASĀYAN J. Chem.

Vol. 11 | No. 2 | 465 - 474 | April - June | 2018

\begin{tabular}{l|l|l|l}
2 & 32.183 & 62.100 & 1.930 \\
\hline 3 & 32.338 & 46.500 & 1.438 \\
\hline
\end{tabular}

\section{Change in Acid Number}

The TAN values of the oxidized oil samples are given in Table-6.

Table-6: IP 48: Change in acid number

\begin{tabular}{|c|c|c|c|c|c|c|c|}
\hline \multirow[t]{2}{*}{ Blend } & \multirow{2}{*}{$\begin{array}{l}\text { Sample Weight, gm } \\
\qquad m_{s}\end{array}$} & \multirow{2}{*}{$\begin{array}{c}\mathrm{KOH} \\
\text { Normality, N } \\
C_{\mathrm{KOH}}\end{array}$} & \multirow{2}{*}{$\begin{array}{l}\text { Blank, } \\
\text { ml } \\
V_{\text {blank }}\end{array}$} & \multicolumn{2}{|c|}{$\begin{array}{c}\text { Endpoint, volume, } \mathrm{ml} \\
\quad V_{\text {last } E P}\end{array}$} & \multicolumn{2}{|c|}{$\begin{array}{l}\text { TAN, mg } \\
\mathrm{KOH} / \mathrm{gm}\end{array}$} \\
\hline & & & & EP 1 & EP 2 & EP 1 & EP 2 \\
\hline 1 & 0.6608 & 0.0668 & 0.0590 & 1.7964 & 1.5929 & 9.85 & 8.70 \\
\hline 2 & 0.9802 & 0.0850 & 0.0530 & 1.5317 & 1.3397 & 7.19 & 6.26 \\
\hline 3 & 0.8810 & 0.0850 & 0.0530 & 0.8025 & 0.6974 & 4.06 & 3.49 \\
\hline
\end{tabular}

Carbon Residue content

Carbon residue values for oxidized oils of Blend-1, 2 and 3 are given in Table-7.

Table-7: IP 48: Carbon Residue content

\begin{tabular}{c|c|c|c|c|c|c}
\hline Blend & $\begin{array}{c}\text { The weight of } \\
\text { Empty Vial, } \\
\text { gm }\end{array}$ & $\begin{array}{c}\text { The weight } \\
\text { of Vial + Oil } \\
\text { Sample, gm }\end{array}$ & $\begin{array}{c}\text { Sample } \\
\text { Weight, gm }\end{array}$ & $\begin{array}{c}\text { Final } \\
\text { Weight, gm }\end{array}$ & $\begin{array}{c}\text { Carbon } \\
\text { residue, gm }\end{array}$ & $\begin{array}{c}\% \text { Weight } \\
\text { Residue }\end{array}$ \\
\hline 1 & 2.9062 & 3.9423 & 1.0361 & 2.9125 & 0.0063 & 0.6080 \\
\hline 2 & 2.9373 & 3.9795 & 1.0422 & 2.9405 & 0.0032 & 0.3070 \\
\hline 3 & 2.9139 & 3.9424 & 1.0285 & 2.9161 & 0.0022 & 0.2139 \\
\hline
\end{tabular}

\section{Oxidation Products by FTIR}

Oxidized lubricants show strong broad $\mathrm{O}-\mathrm{H}$ stretching band in the $3230-3600 \mathrm{~cm}^{-1}$ region. The $\mathrm{C}=\mathrm{O}$ stretching band of free acid at higher wave number at $1760 \mathrm{~cm}^{-1}$. In addition to these, samples show characteristic C-O stretching in 1320-1210 $\mathrm{cm}^{-1}$ range and, in-plane O-H bending at 1440-1395 $\mathrm{cm}^{-1}$. However, these absorptions are so weak to get detected significantly.

In FTIR Spectra of fresh oil Blend-2 and Blend-3, apart from normal phenolic O-H absorption at $3651 \mathrm{~cm}^{-}$ ${ }^{1}$, the strong absorption band at $\sim 1744 \mathrm{~cm}^{-1}$ is observed due to $\mathrm{C}=\mathrm{O}$ stretching whose force constant is increased due to the electron attracting nature (inductive effect) of adjacent oxygen atom of the $\mathrm{C}-\mathrm{O}$ bond. $\mathrm{C}-\mathrm{S}$ stretching vibrations in AO-III is weak and not detectable in the complex matrix, which otherwise could fall between $700-600 \mathrm{~cm}^{-1}$.

ASTM E2412 provides test protocol for direct trending as well as by spectral subtraction. Direct trending suggests oxidation estimation by measuring area between 1800 and $1670 \mathrm{~cm}^{-1}$. This measures the concentration of carbonyl compounds due to carboxylates and can be related to the concentration of oxidation products in the oil.

The test procedure as ASTM E 2412 was followed, however, instead of the area of the peak in the range of 1800 to $1670 \mathrm{~cm}^{-1}$; transmittance at the peak maximum in this wavenumber range is taken for further analysis. Generally, the peak in this range is broad due to the presence of various carbonyl-containing degradation products of the oil. These could contain lactones, esters, aldehydes, ketones, carboxylic acids. The transmittance of samples at peak maxima of carbonyl compounds $\left(1718 \mathrm{~cm}^{-1}\right)$ was measured and values of optical density calculated to represent the concentration of the oxidation products generated.

The transmittance and optical density data of oil, before and after oxidation, is summarized in Table -8 . 
RASĀYAN J. Chem.

Vol. 11 | No. 2 |465 - 474 | April - June | 2018

Table-8: Transmittance and Optical Density.

\begin{tabular}{c|c|c|c|c}
\hline Blend & $\begin{array}{c}\text { The transmittance } \\
\text { of the oil before } \\
\text { oxidation, Io }\end{array}$ & $\begin{array}{c}\text { The transmittance of } \\
\text { the oil after } \\
\text { oxidation, I }\end{array}$ & Io/I & $\begin{array}{c}\text { Optical Density, A } \\
\text { = Log (IO/I) }\end{array}$ \\
\hline 1 & 0.5735 & 0.0056 & 102.41 & 2.01 \\
\hline 2 & 0.5588 & 0.0078 & 71.64 & 1.86 \\
\hline 3 & 0.5567 & 0.0466 & 11.95 & 1.08 \\
\hline
\end{tabular}

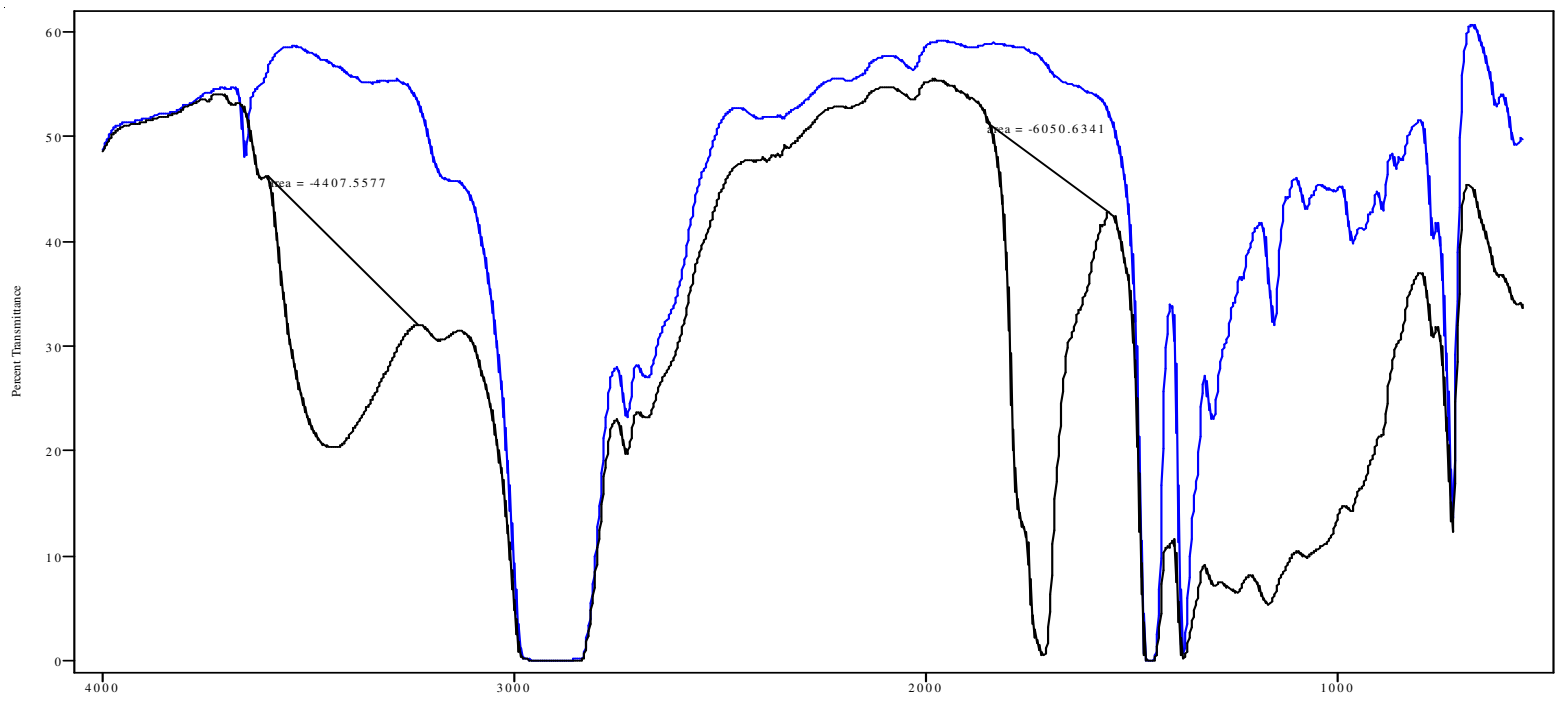

Fig.-1: Un-oxidized and Oxidized Oil Spectra with Blend-1

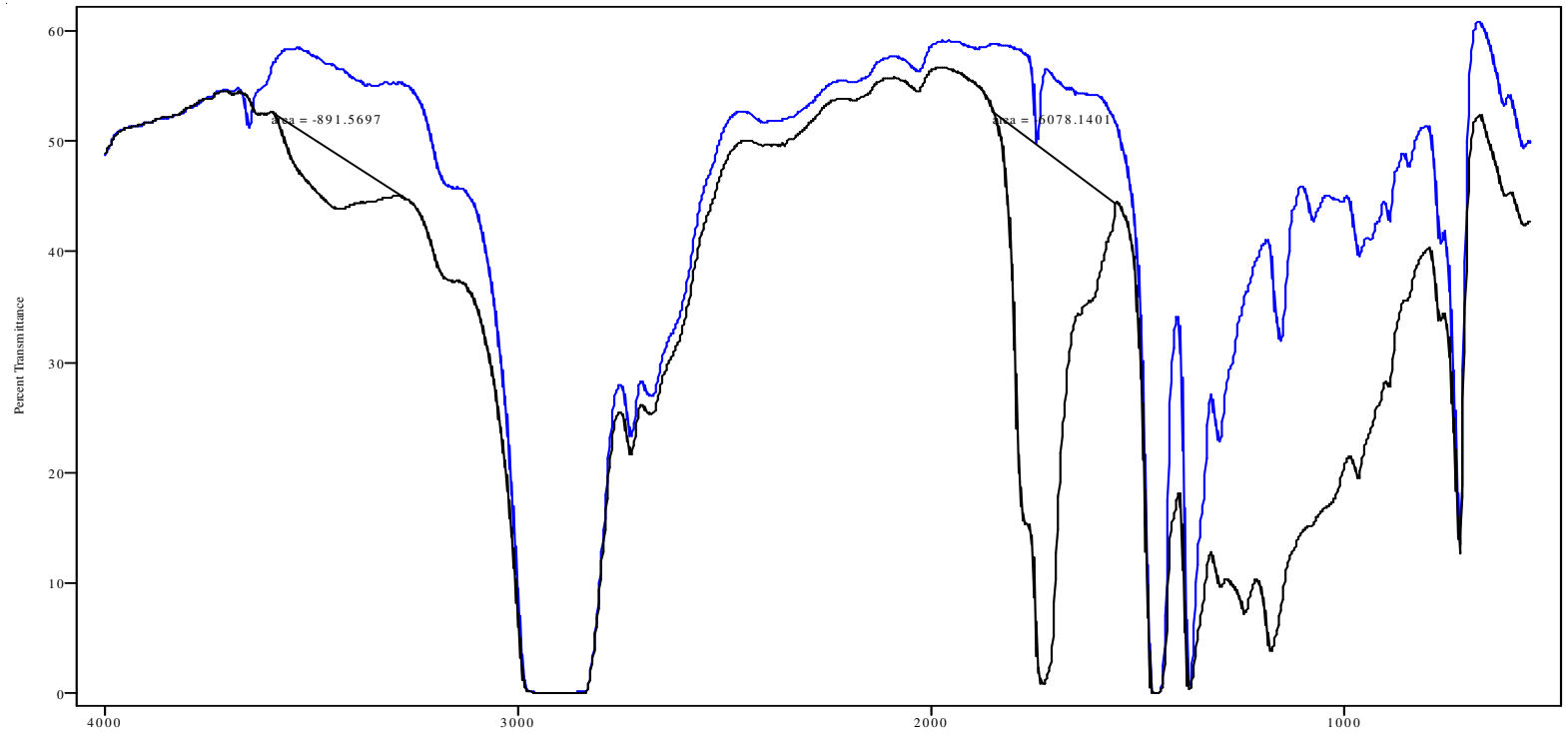

Fig.-2: Un-oxidized and Oxidized Oil Spectra with Blend-2

Comparative summary of IP -48 oxidation test data is given in Table- 9 .

Table-9: IP 48: Summary of Test results

\begin{tabular}{c|c|c|c|c|c|c}
\hline \multirow{3}{*}{ Blend } & $\begin{array}{c}\text { \% Weight } \\
\text { loss }\end{array}$ & \multicolumn{2}{|c|}{$\begin{array}{c}\text { TAN, mg } \\
\text { KOH/gm }\end{array}$} & $\begin{array}{c}\text { Variation in } \\
\text { Viscosity }\end{array}$ & $\begin{array}{c}\text { Optical Density, } \\
\text { A = Log (IO/I) }\end{array}$ & \% Weight Residue \\
\cline { 3 - 4 } & EP 1 & EP 2 & & \\
\hline
\end{tabular}


RASĀYAN J. Chem.

Vol. 11 | No. 2 |465 - 474 | April - June | 2018

\begin{tabular}{l|c|c|c|c|c|c}
1 & 10.3 & 9.85 & 8.70 & 3.029 & 2.01 & 0.61 \\
\hline 2 & 7.4 & 7.19 & 6.26 & 1.930 & 1.86 & 0.31 \\
\hline 3 & 5.6 & 4.06 & 3.49 & 1.438 & 1.08 & 0.21 \\
\hline
\end{tabular}

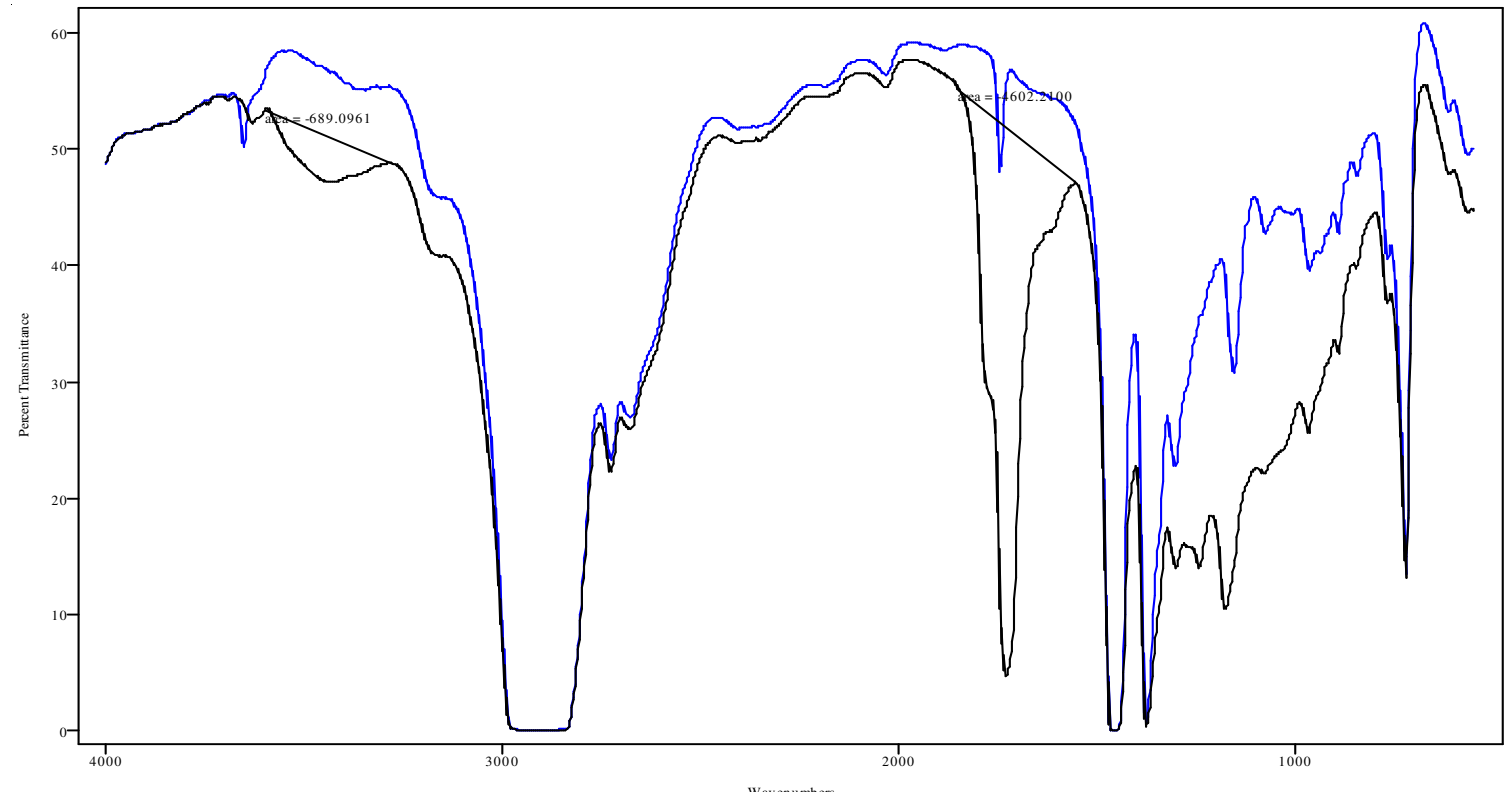

Fig.-3: Un-oxidized and Oxidized Oil Spectra with Blend-3

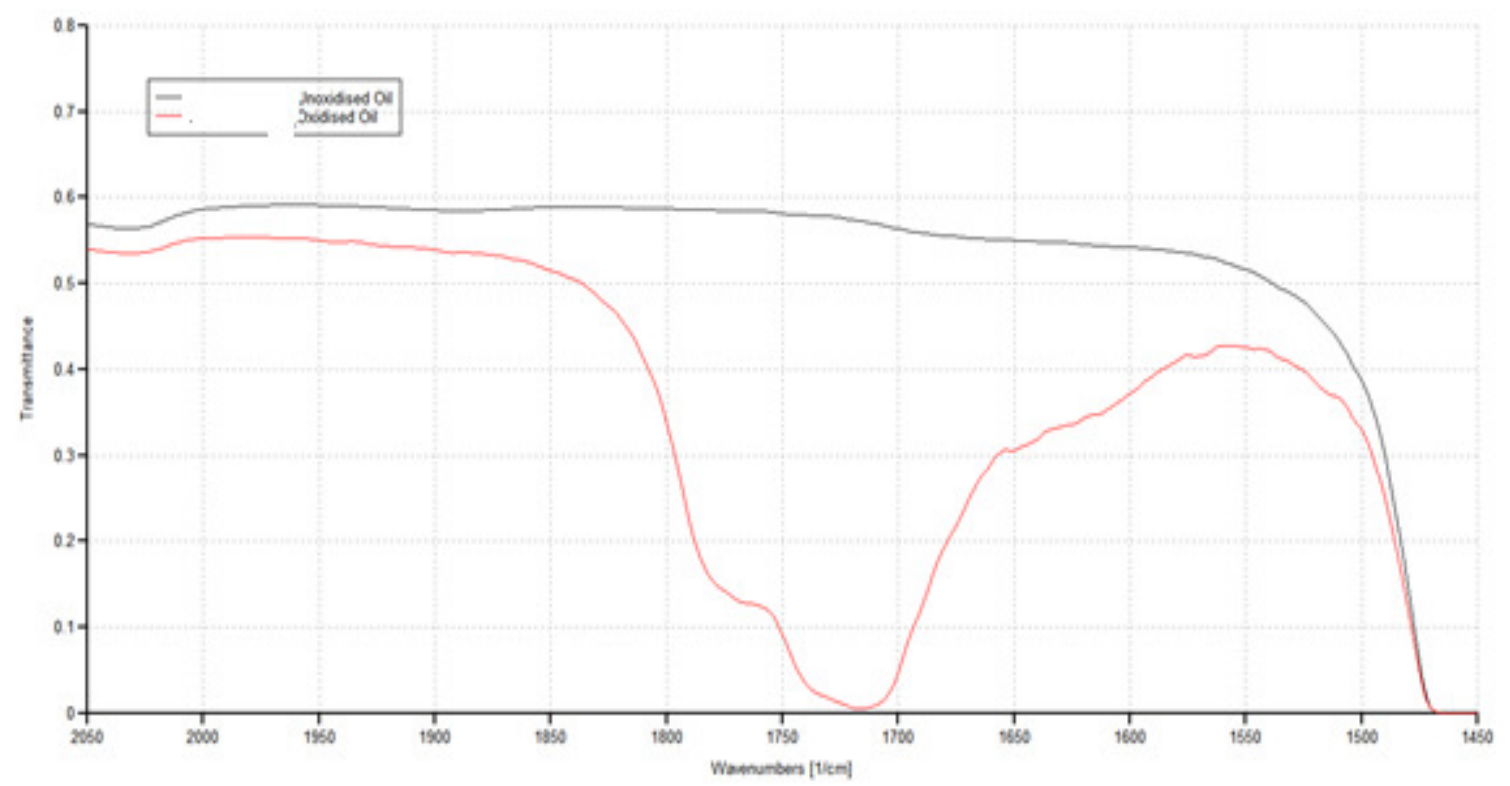

Fig.-4: FTIR Spectrum of Un-oxidized and Oxidized Oil Blend-1

Lower weight loss, lower TAN value, lower variation in viscosity, lower optical density and lower residue percentage denotes the better inhibition capacity of antioxidant.

The Antioxidant Activity by Isothermal PDSC.

The plot of Heat Flow (W/g) against runtime (minutes) for three Antioxidant Blends is given in below Fig.7 to 9. 
RASĀYAN J. Chem.

Vol. 11 | No. 2 | 465 - 474 | April - June | 2018

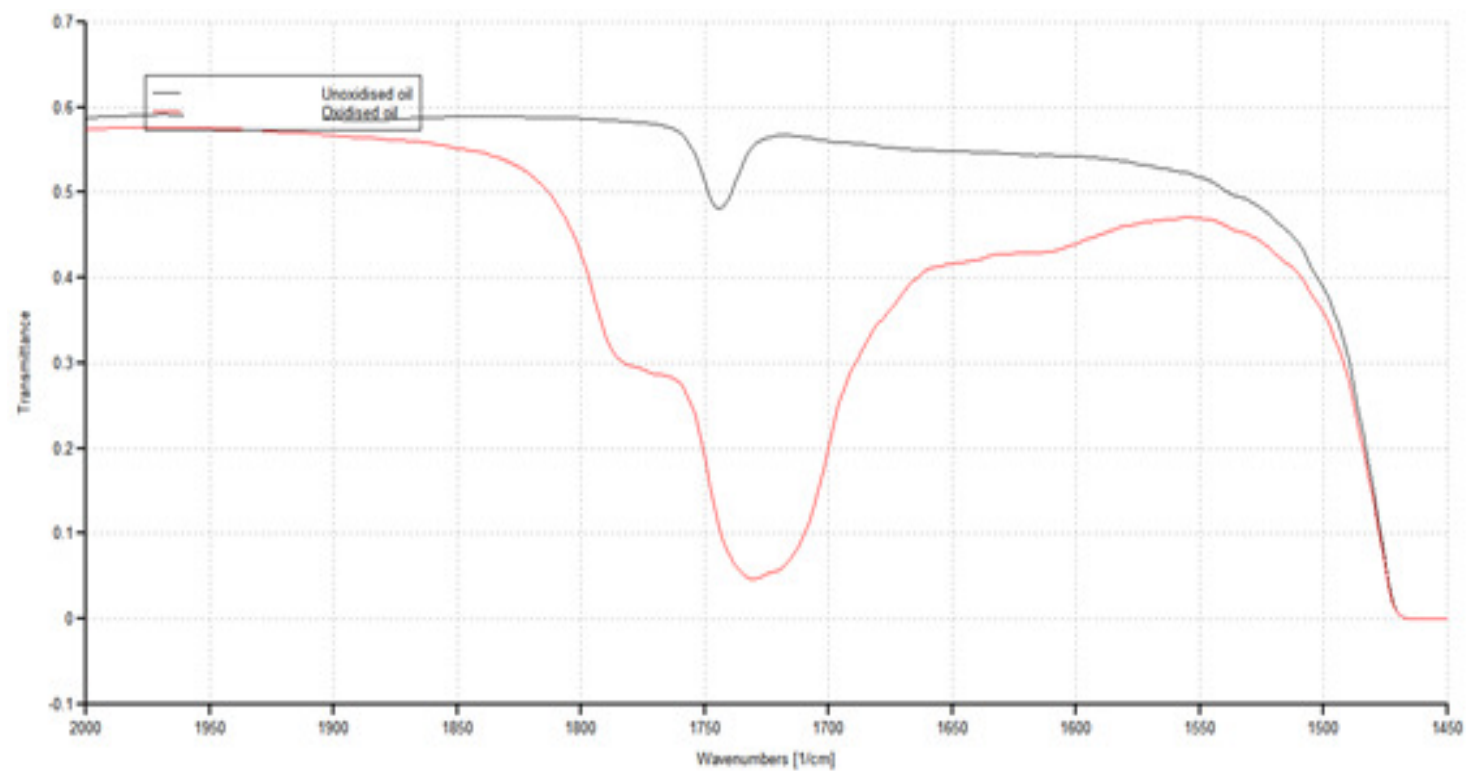

Fig.-5: FTIR spectrum of un-oxidized and oxidized oil Blend-2

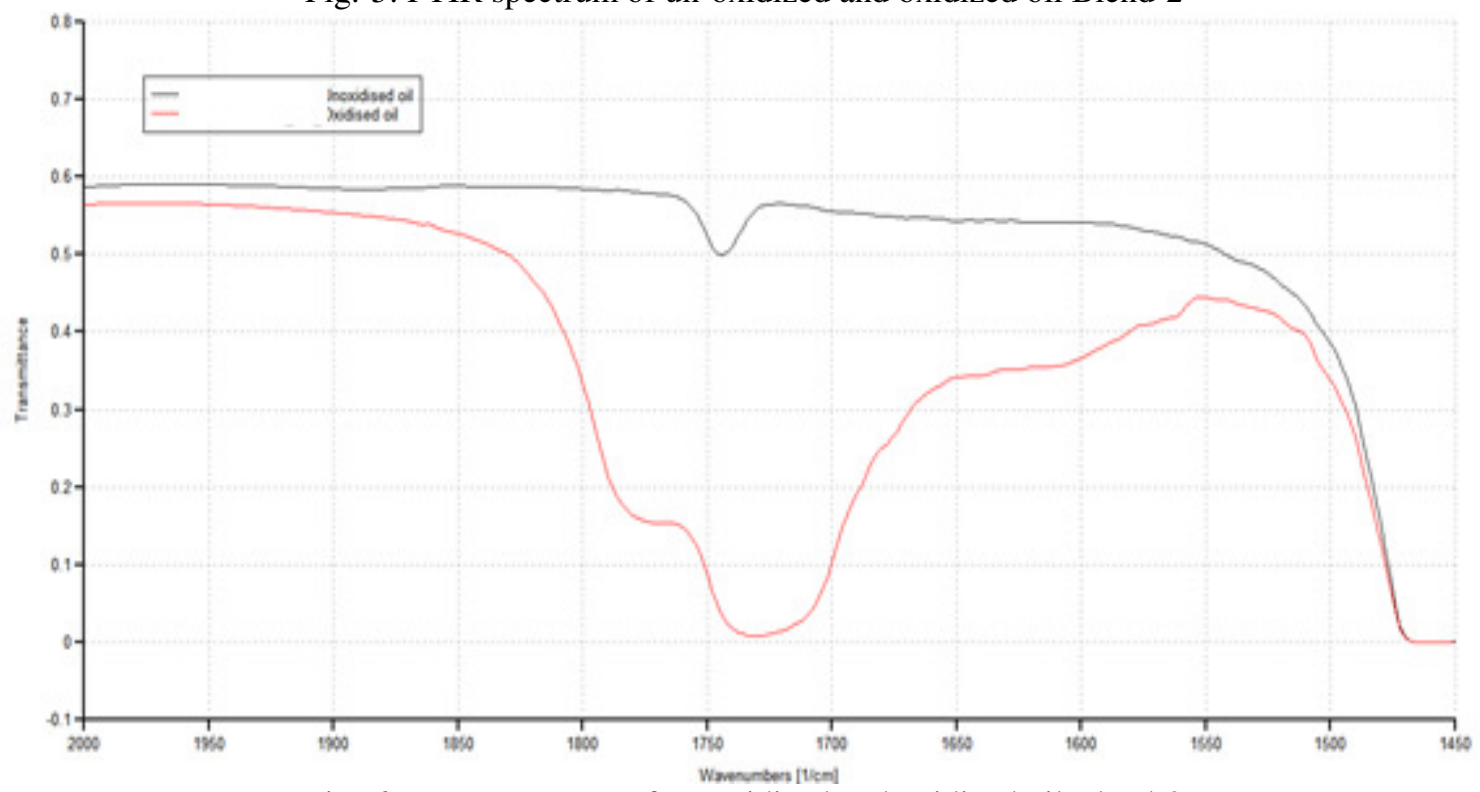

Fig.-6: FTIR spectrum of un-oxidized and oxidized oil Blend-3

The OIT values obtained by Isothermal PDSC for Blend 1-3 are given below:

\begin{tabular}{c|c|c|c}
\hline & Blend-1 & Blend-2 & Blend-3 \\
\hline OIT, minutes & 19.35 & 44.00 & 46.82 \\
\hline
\end{tabular}

Higher the OIT in minutes denotes the longer the oil can withstand oxidation inhibition and longer the useful life.

\section{CONCLUSION}

From the test results of IP-48 and PDSC, it is concluded that:

1. The inhibitory activity of antioxidants in bulk oil, as well as thin film oxidation test observed, is AOIII > AO-II >AO-I. The relative activity of the selected antioxidants is similar in both the oxidation regimes. 
RASĀYAN J. Chem.

Vol. 11 | No. 2 | 465 - 474 | April - June | 2018

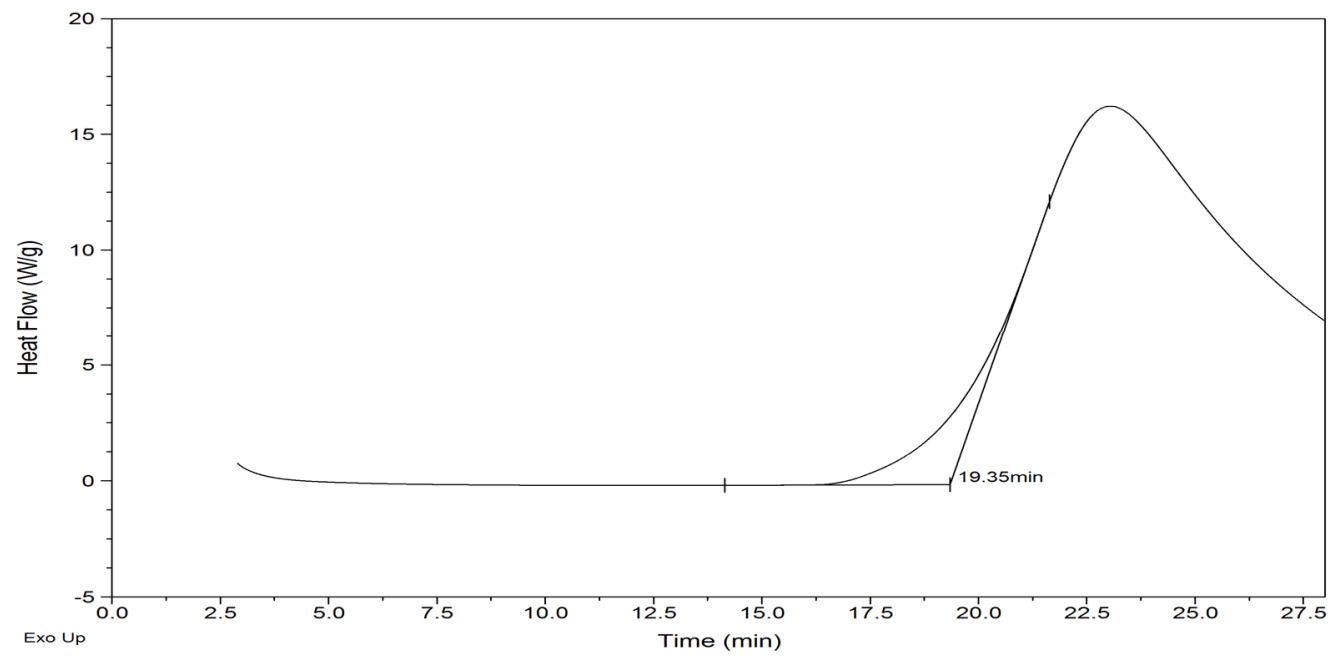

Fig.-7: PDSC Curve for Blend-1 at $180^{\circ} \mathrm{C}$

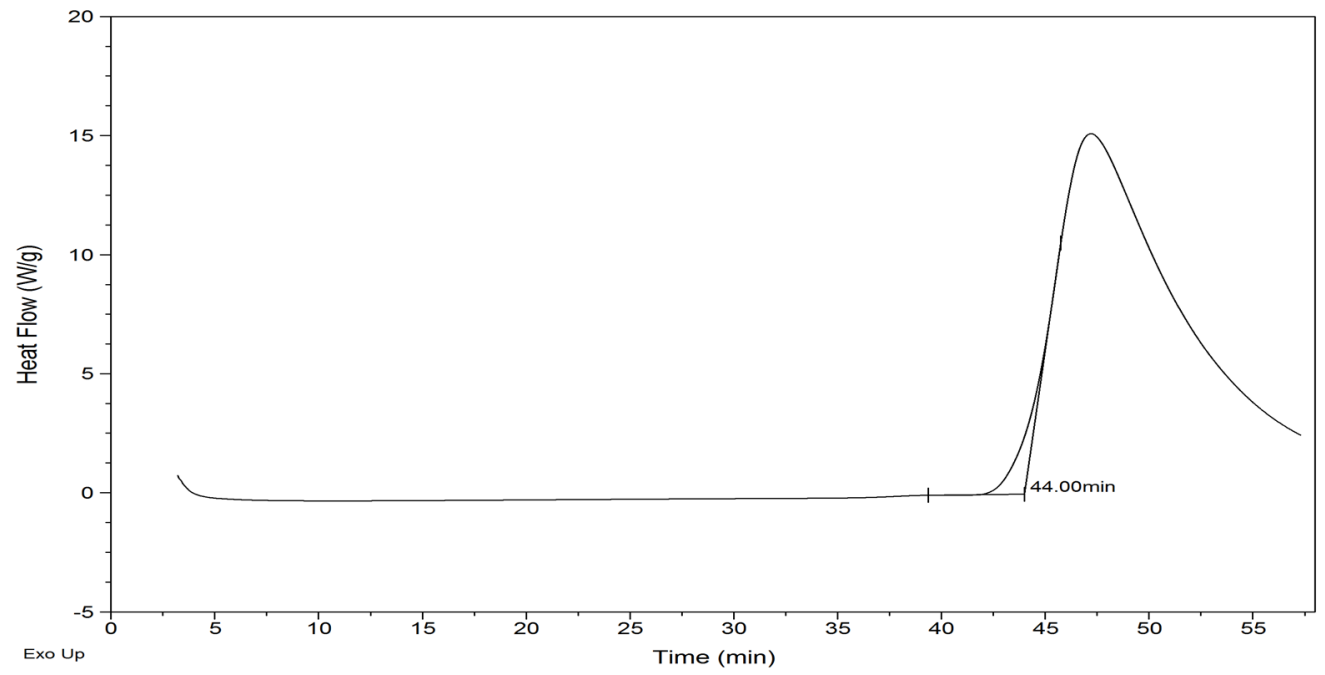

Fig.-8: PDSC Curve for Blend-2 at $180^{\circ} \mathrm{C}$

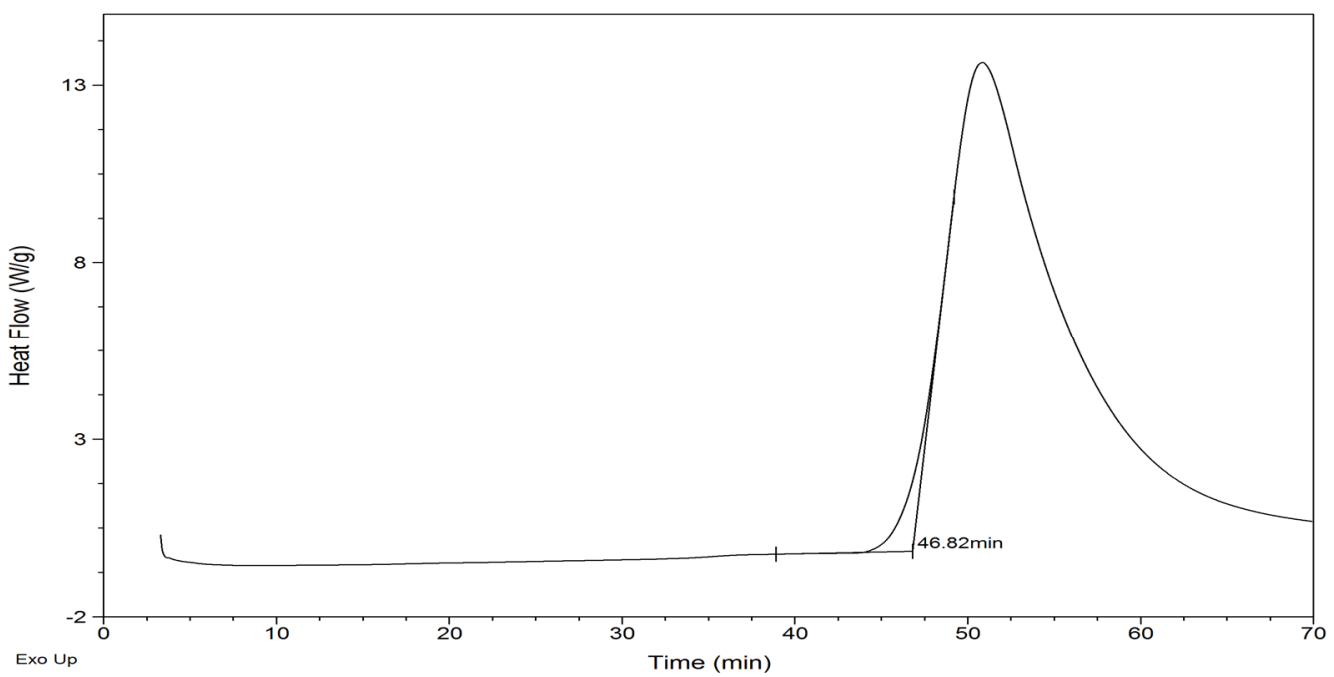

Fig.-9: PDSC Curve for Blend-3 at $180^{\circ} \mathrm{C}$ 
2. Ester functional group in the para position of the phenolic -OH group give better stability of phenoxy radical as compared to the methyl function group. Hence antioxidant activity of AO-II is much better that AO-I in both the oxidation regimes.

3. AO-III antioxidant with thioether linkage is given highest oxidation stability amongst three blends. An ester of thiodipropionic acid is capable of decomposing stoichiometrically more number of hydroperoxide radicals formed in the initiation reaction of oxidation. AO-III is, therefore, exhibiting highest antioxidant activity in the selected AO samples.

\section{ACKNOWLEDGMENT}

The authors express their gratitude to Authorities of JJTU, Bhavan's College and the Management of Bharat Petroleum Corporation Ltd. for granting permission to publish this work.

\section{REFERENCES}

1. A. M. H. Syah Lubis, B. Ariwahjoedi, M.Sudin, S. Parman., Applied Mechanics and Materials, 393, 893(2013), DOI:10.4028/www.scientific.net/AMM.393.893

2. S. Nallusamy, J. Logeshwaran, Rasayan Journal of Chemistry, 10(3), 1050(2017), DOI:10.7324/RJC.2017.1031861

3. J. Dong, C. A. Migdal, 2009, Antioxidants, in L.R.Rudnick (Eds.), Lubricant Additives Chemistry and Applications Second Edition, CRC Press, New York, pp. 4-41.

4. D.M. Brown, A. Fish in Proceedings of the Royal Society A: Mathematical, Physical and Engineering Science, 308, 547-568 (1969), DOI:10.1098/rspa.1969.0025.

5. R.Thomas, M. Dexter, R.E. King III, 2002, Antioxidants, Polymers, Kirk-Othmer Encyclopedia of Chemical Technology. John Wiley \& Sons, Inc., pp.102-134. DOI:10.1002/0471238961.0114200904052420.a01.pub2.

6. Determination of Oxidation Characteristics of Lubricating Oil. IP 48 (2012), Energy Institute, Londan.

7. Standard Test Method for Oxidation Induction Time of Lubricating Oils by Pressure Differential Scanning Calorimetry (PDSC), ASTM D6186-08 (2013), DOI:10.1520/D6186.

8. J.R.S. Politi, P.R.R. Matos, M.J.A.Sales, D. Journal of Thermal Analysis and Calorimetry, 111(2), 1437(2013), DOI:10.1007/s10973-012-2529-6.

9. $\quad$ B.K.Sharma, U. Rashid, F.Anwar, S.Z. Erhan, Journal of Thermal Analysis and Calorimetry, 96 (3), 999(2009), DOI:10.1007/s10973-009-0066-8.

10. M.A. De Sousa Rios, S.E. Mazzetto, Journal of Thermal Analysis and Calorimetry,111(1), 553 (2013). DOI:10.1007/s10973-011-2160-y.

11. M.A.S. Rios, F.F.P Santos, F.J.N. Maia, S.E.Mazzetto. Journal of Thermal Analysis and Calorimetry, 112 (2), 921(2013), DOI:10.1007/s10973-012-2650-6.

12. Standard Test Method for Kinematic Viscosity of Transparent and Opaque Liquids (and Calculation of Dynamic Viscosity), ASTM D445-17a, DOI:10.1520/D0445-17A.

13. Standard Test Method for Acid Number of Petroleum Products by Potentiometric Titration, ASTM D664-17, DOI: 10.1520/D0664-17

14. Standard Test Method for Determination of Carbon Residue (Micro Method), ASTM D4530-15, DOI:10.1520/D4530-15

15. F.R Van De Voort, J.Sedman, R.A. Cocciardi, D.Pinchuk,Tribology Transactions, 49(3), 410 (2006), DOI:10.1080/10402000600781432

16. Standard Practice for Condition Monitoring of Used Lubricants by Trend Analysis Using Fourier Transform Infrared (FT-IR) Spectrometry. ASTM E2412-10, DOI:10.1520/E2412-10

17. C. Qiu, S. Han, X.Cheng, T. Ren, T. Thermochimica acta, 447(1), 36(2006), DOI:10.1016/j.tca.2006.01.014

18. B.K.Sharma, A. Adhvaryu, J.M.Perez, S.Z. Erhan, Journal of Agricultural and Food Chemistry, 53, 2961(2005), DOI: 10.1021/jf0486702

[RJC-2052/2017] 